\title{
A high proportion of Norway spruce in mixed stands increases probability of stand failure
}

\author{
Joerg Roessiger*, Ladislav Kulla, Maroš Sedliak \\ National Forest Centre - Forest Research Institute Zvolen, T. G. Masaryka 2175/22, SK - 96001 Zvolen, Slovak Republic
}

\begin{abstract}
The decline of pure spruce forests in the Beskydy Mountains in the Czech Republic and Slovakia is mainly driven by bark beetle attacks and storm events. Salvage-harvest records based on timber volume on the forest-stand level document the extent of stand failure processed by salvage logging. On the basis of these records, the stand failure proportion was expressed as the proportion of timber volume processed by salvage harvest divided by the standing timber volume over a period of 10 years ( $s f)$. Two null hypotheses to be tested are that $s f$ is not influenced by $(\mathrm{H} 1)$ the size of trees expressed by mean stand age (age) or alternatively by mean stand diameter $(d b h)$; and (H2) the volume proportion of spruce within the stand (spp). The dataset was evaluated as a total and separately for the three site types, each for spruce, beech, fir, larch, pine, and other broadleaved species. The dataset was analysed using a binary logistic regression. The sf increased with age, $d b h$, and the spp. Pure spruce stands with high age and high $d b h$ on mountain sites are associated with the highest $s f$. However, a slight admixture of $25 \%$ tree species other than spruce was shown to stabilise the stands significantly. Species other than spruce in a minor admixture to spruce stands were destabilised by the breakdown of spruce stands. For a realistic financial evaluation of forest-stand management, managers should consider the risk of stand failure, and reduce the risk by increasing species admixture in the spruce forest stands.
\end{abstract}

Key words: stand failure; risk; forest management planning; stabilisation; probability of survival

Editor: Martin Lukáč

\section{Introduction}

Old, pure even-aged spruce forests are rapidly declining in the Carpathian Mountains (Hlásny \&Sitková 2010; Kulla \& Sitková 2012; Hlásny et al. 2017). The initial event was a storm in 2004 that caused wind throws in old spruce stands. Storms in combination with hot dry summers are weakening spruce vitality and encouraging the spread of bark beetle and, thus, the further dying of whole stands on a large scale (Hlásny \& Sitková 2010), which has mainly been seen since 2004. Forest management utilises a high amount of salvage cutting, which provokes debates regarding the different perspectives of spruce forest management.

Some general reasons discussed for the high intensity of spruce stand failure in the Carpathian Mountains are as follows:

- Climate change generating hot dry summers and warmer winters;

- Previous forest management strategies expanding spruce to unsuitable sites;

- Low thinning intensity leading to dense stands with short crowns, reducing single-tree stability and vitality;
- The prolonging of rotation periods to higher ages, which leads to exposure to a greater amount of risks;

- Pure, even-aged spruce forests rather than unevenaged forests being mixed with fir and beech.

Nevertheless, from the point of view of a forest manager, spruce is the most productive species due to its fast growth, short rotation cycles, and the cheap, schematic stand treatment. As a result of its high timber quality, spruce is in demand in forest industries. Additionally, because of natural spruce regeneration in the study region, often no planting is necessary. Contrarily, missing seed trees and insufficient or delayed natural regeneration from alternative species like fir and beech creates the need for expensive tree-planting programs. Moreover, adaptive management might even consider intermixing with non-native tree species in the face of shifts in the natural distribution areas caused by climate change (Bolte et al. 2009).

There are alternative solutions in the face of the high frequency of stand failure which will allow for continuous forest management in the future. As a possible solution, mixed rather than pure forests can reduce risks (Gayer 
1886; Knokeet al. 2005). "Near-natural forestry”, “closeto-nature forestry", or "continuous-cover forestry" are terms which have no exact definition but typically mean the use of natural processes for management purposes and the avoidance of clearcuts.

Admixing of other tree species strongly reduces the risk of spruce stand failure and increases stability. Griess et al. (2012) and Roessiger et al. (2013) demonstrated that even a low admixture of $20 \%$ of broadleaved species to a pure spruce stand has a big effect on stabilisation while further admixture did not have an important impact on a stand with a low spruce area proportion. The reasons discussed for the stabilisation effect related to a lower failure risk (Knoke \& Seifert 2008; Knoke et al. 2008; Griess \& Knoke 2011; Griess et al. 2012) are as follows:

- The different types of roots using different soil horizons (the deeper roots of broadleaved species compared to spruce);

- The deeper and longer crown of broadleaved species, as compared to spruce, blocking the wind;

- The distinct or slower mechanical oscillation frequencies of broadleaved species reducing wind throws and breakage of spruce dominated stands during storms;

- Longer flight distances for bark beetles to reach the next spruce tree reducing beetle vitality;

- More ecological niches for antagonists against bark beetles or pathogens;

- Soil improvement by faster recycling of litter by broadleaved species.

While the mentioned ecological benefits are difficult to measure, the failure probabilities can be quantified with statistical regression models to estimate the countable financial long-term consequences when comparing the forests management options of pure spruce and mixed forests.

A regression model to estimate failure dependent on age based on Weibull function (Staupendahl \& Zucchini 2011) was developed to also consider stabilisation of spruce forests by beech admixture for regional studies in Germany (Griess et al. 2012; Neuner et al. 2015) and on a pan-European dataset on crown condition on Level
1 and Level 2 plots (Paul et al. 2019; Brandl et al. 2020). The regional studies from Germany need to also be tested for other regions and conditions, and with a different type of dataset. While all the cited studies used plot-inventory data based on the individual tree level, the new application tests a salvage-harvest records based on timber volume. Existing statistical studies using mortality data in the Czech Republic and Slovakia (Pajtík et al. 2018) and salvage felling in Slovakia (Kunca et al. 2019) report average values but no regression models. Therefore, the new application in this study incorporates species mixture for spruce and other species into regression models for $s f$ for the case of the Beskydy Mountains in Slovakia and the Czech Republic, which represent typical conditions in Central/Eastern European mountain forests.

Two null hypotheses to be tested are that stand failure $s f$ (expressed by timber volume proportion processed by salvage logging over a period of 10 years) is not influenced by the following:

- H1: the size of trees expressed by mean stand age or alternatively by mean stand diameter;

- H2: the proportion of spruce within the stand.

\section{Materials and method}

Data from Forest management plans and Forest management records collected within a cross boundary project Interreg BESKYDY were used as the input for the analysis (Consortium Beskydy, 2019). The data cover 71,436 hectare of compact forest in the West Carpathian mountains, lying on both sides of the Czecho-Slovakian border. The project area is represented by the Protected landscape area of Beskydy in the Czech Republic, and the Protected landscape area of Kysuce in Slovakia (Fig. 1).

The territory is made up of flysh rocks with eutric, haplic, gleic, or dystrict cambisols with transitions to podsols in the upper parts, and luvisols in the lower parts. Tree species composition was significantly changed by the management in the past. Pure, even-aged spruce or mixed spruce stands predominate. Other spe-cies domi-

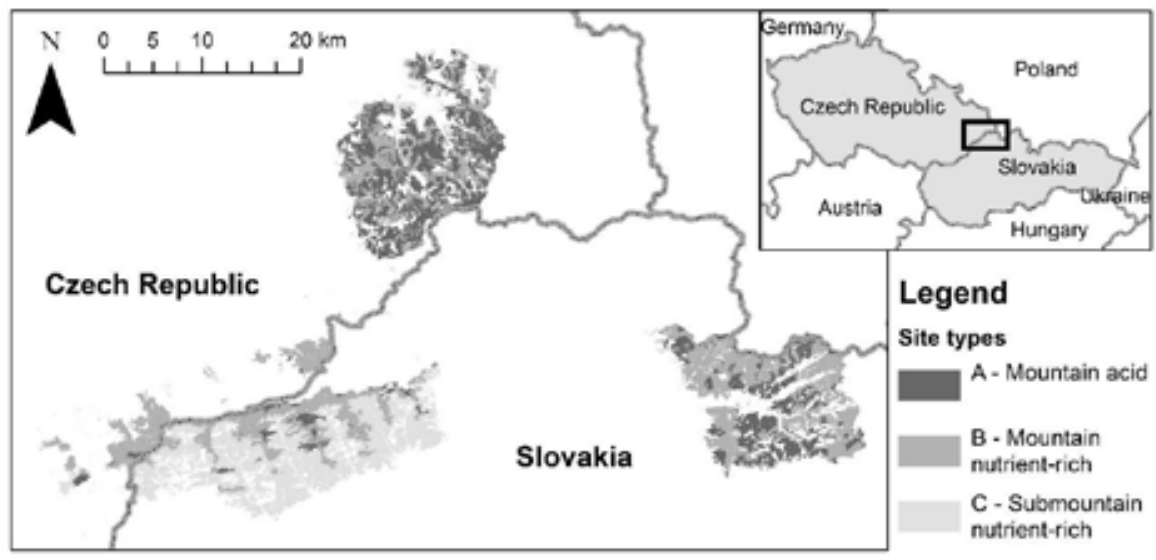

Fig. 1. The location of forest land covered by the data utilised for the analysis. 
nating is less common, but there are cases in the foothills and in remote parts of the mountainous region, which were saved from intensive management in the past.

To also evaluate influence of site on stand failure, the territory dataset was split into three site types (Fig. 1):

- A: Mountain acid; including the mountain zone of beech-fir and beech-fir-spruce altitudinal vegetation zone (AVZ) on acid soils, $800-1300$ m a.s.l.;

- B: Mountain nutrient-rich; including the mountain zone of beech-fir and beech-fir-spruce AVZ on normal and rich soils, $800-1300 \mathrm{~m}$ a.s.l.;

- C:Sub-mountain nutrient-rich; including the foothill zone of beech AVZ on normal and rich soils, $300-$ 800 m a.s.l. (Zlatník, 1976).

Furthermore, the dataset was divided into six species groups (Table 1).

Table 1. Tree species composition calculated from standing volume per site type. Other broadleaved species mainly comprise hornbeam and oak.

\begin{tabular}{lccccccc}
\hline Site & Spruce & Beech & Fir & Pine & Larch & $\begin{array}{c}\text { Other broadleaved } \\
\text { species }\end{array}$ & Total \\
\hline A & $88.9 \%$ & $6.5 \%$ & $3.7 \%$ & $0.3 \%$ & $0.2 \%$ & $0.3 \%$ & $100.0 \%$ \\
B & $75.2 \%$ & $17.0 \%$ & $5.8 \%$ & $0.2 \%$ & $0.6 \%$ & $1.2 \%$ & $100.0 \%$ \\
C & $56.8 \%$ & $24.3 \%$ & $8.5 \%$ & $5.8 \%$ & $2.6 \%$ & $2.1 \%$ & $100.0 \%$ \\
\hline
\end{tabular}

A regression model was used to calculate the salvageharvest proportion of standing timber volume (Fig. 2) per species and per stand during the period 2009-2018.

Few errors were found in the original dataset. Illogical values with a $s f$ higher than $120 \%$, i.e. a salvage volume higher than the standing timber volume per species were removed from the analyses (652 cases were deleted). Cases with $s f$ up to $20 \%$ higher than the standing volume were considered to be $100 \% s f$ regarding the increment between the inventory and the stand failure event, i.e., they were considered as possible errors in measurement (356 cases were corrected). Furthermore, cases with no volume per species, which counts for young stands, were not included (3,797 cases were deleted). Finally, 52,459 single cases were included into regression.

An evaluation using binary logistic regression was chosen, as it constrains the probability between $0 \%$ and $100 \%$, it is flexible in terms of varying the steepness of the increase of the function, and it allows the scale to be shifted. The regression was carried out with the general linear model (GLM) function in the R statistical software (R Core Team, 2019). Two models were alternatively applied to test the hypotheses. The dependent variable was stand failure probability and the independent variables were as follows:

- Model 1 (M1): age of a species and spp;

- Model 2 (M2): dbh of a species and spp.

$$
\begin{aligned}
& M 1: s f=\frac{1}{1+\operatorname{EXP}\left(-\left(c_{0}+c_{1} * a g e+c_{2} * s p p\right)\right)} \\
& M 2: s f=\frac{1}{1+\operatorname{EXP}\left(-\left(c_{0}+c_{1} * d b h+c_{2} * s p p\right)\right)}
\end{aligned}
$$

Here, $s f$ is decenal probability of stand failure (proportion calculated by the salvage-harvest volume divided by the standing timber volume over a period of 10 years) of a species in a stand; age is the mean age of a tree species in a forest stand in years; $d b h$ is the mean diameter at breast height of a tree species in a forest stand in $\mathrm{cm}$; and spp is the relative proportion of spruce volume divided by the total forest-stand volume on the stand level.

Dbh and age closely correlate. The reason for the alternative approach based once on age and once on $d b h$ was to obtain potentially usable stand failure models for both: The common management based on age classes, as well as the close-to-nature or selective management based on diameter classes.

The regression model includes a weighting by total stand area in hectare to consider how representative the stand is in the total area.

Proportion of tree species other than spruce in the forest stand was not included as a further coefficient due

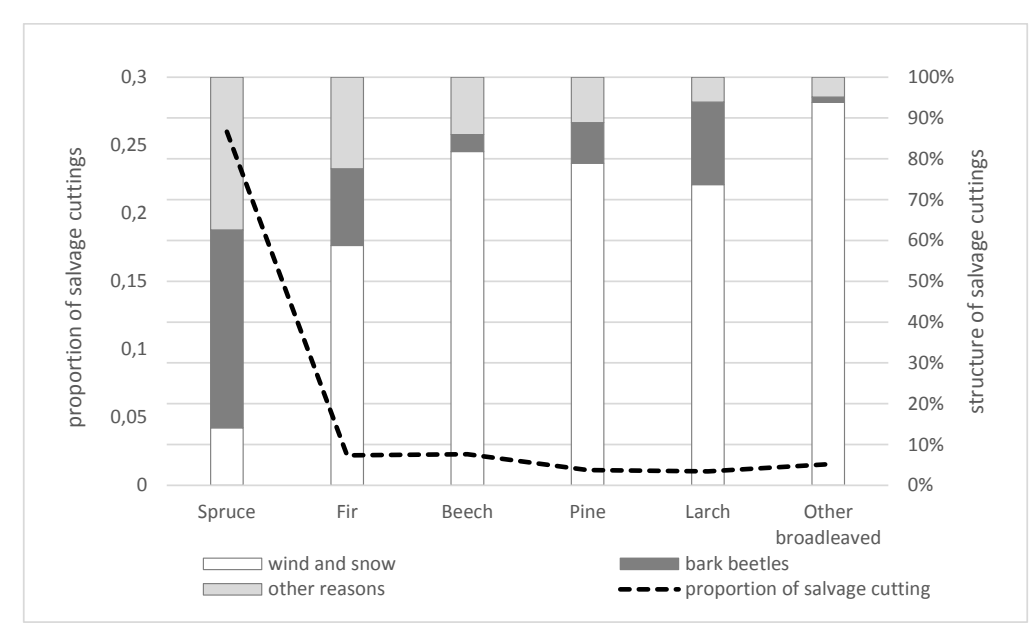

Fig. 2. Proportion of and reasons for salvage cutting as a result of harmful agents 2009-2018 (only the Slovakian part of the territory as it had data on the reason for dieback; the other reasons are air pollution and drought). 
to its negative correlation to spp and due to the lower amount of data relate to the higher proportion of admixture of species other than spruce.

\section{Results}

Stand failure and subsequent salvage cutting increase with age and spp or $d b h$ and spp (Fig. 3). This holds true for all the evaluated species groups and on all the sites evaluated. The only limited cases are the insignificant models for pine on sites $\mathrm{A}$ and $\mathrm{B}$, other broadleaved species on site A both for M1, as well as pine on site A, and larch on site B both for M2 (Table 2). These cases occurred mainly on sites and for species where the number of cases was small and the increase in the functions was relatively small.

Spruce admixture had the biggest effect on $s f$ for the interval between $100 \%$ and $75 \%$ spp, while lower spp mainly had a minor impact on $s f$. In the case of nearly no spp, only spruce on sites A and B both had a high sf of $10 \%$ and more for an age of 120 years or a $d b h$ of $50 \mathrm{~cm}$, while for all other cases $s f$ was less than $8 \%$. For nearly no spp and an an age of 120 years pine and other broadleaved species both on site $C$ had a low sfaround $2.5 \%$. Nevertheless, beech, larch, and other broadleaved species on site $\mathrm{C}$ in a nearly pure spruce stand had a $s f$ nearly as high as the $s f$ of spruce. This clarifies that spruce management is always risky for spruce in the mountainous regions of Beskydy. For species other than spruce, management is risky when the species are a minority admixed in a nearly pure spruce stand. In the case of a young age in a nearly pure spruce stands only spruce on sites A and B had a high $s f$ of $6 \%$ and $9 \%$, respectively, while all other species had a lower $s f$.
$S f$ of spruce was higher on sites A and B (mountain) compared to C (sub-mountain). Contrarily, $s f$ of beech, other broadleaved species, and larch was higher on site $\mathrm{C}$ compared to sites A and B.

Generally, the results from the two studies regarding age (M1) and $d b h$ (M2) are strongly correlated. Exceptions occurred in the impact of the site on the $s f$ of spruce: $S f$ related to age was higher on nutrient-rich site B (age 120; spp 100\%: 34.2\%) compared to acidic site A (age 120; spp 100\%:30.0\%). Contrarily, spruce sf related to $d b h$ was higher on site $\mathrm{A}(d b h 50 \mathrm{~cm}$; spp $100 \%: 39.6 \%)$ compared to site B ( $d b h 50 \mathrm{~cm}$; spp 100\%: 37.8\%), but only for a high $d b h$.

\section{Discussion}

The results support the effect of species admixture in improving spruce survival, which had already been demonstrated in other studies (Griess et al. 2012; Neuner et al. 2015; Paul et al. 2019; Brandl et al. 2020). Studies such as those by Knoke et al. (2008), Griess et al. (2012), and Roessiger et al. (2013) interpreted the higher survival as a result of the effect of ecological stabilisation of admixed species on spruce.

The survival of spruce depends on beech admixture, but often studies assume the survival of species other than spruce to be constant and independent of the mixture (Griess \& Knoke 2013, Roessiger et al. 2013). The study based in the Beskydy Mountains demonstrated the impact of species mixture, in the form of $s p p$, on $s f$ from beech, fir, pine, larch, and a mixed category of other broadleaved species. This is in line with various studies which showed the effects of admixture on survival, e.g.,

Table 2. Coefficients of the binary logistic regression analysis estimating proportion of stand failure over a 10 year period for Model M1 and Model M2.

\begin{tabular}{|c|c|c|c|c|c|c|c|c|c|c|c|c|c|c|c|c|}
\hline \multirow[b]{2}{*}{ Species } & \multirow[b]{2}{*}{ Site } & \multirow[b]{2}{*}{$\begin{array}{l}\text { Number } \\
\text { of cases }\end{array}$} & \multicolumn{7}{|c|}{ Model 1: Age and spruce proportion } & \multicolumn{7}{|c|}{ Model 2: Diameter and spruce proportion } \\
\hline & & & \multicolumn{2}{|c|}{ Intercept } & \multicolumn{2}{|c|}{$\begin{array}{l}\text { Age } \\
\text { in years }\end{array}$} & \multicolumn{2}{|c|}{$\begin{array}{l}\text { Spruce } \\
\text { proportion in \% }\end{array}$} & \multirow{2}{*}{$\frac{\mathrm{AIC}}{31280}$} & \multicolumn{2}{|c|}{ Intercept } & \multicolumn{2}{|c|}{$\begin{array}{l}\text { Diameter } \\
\text { in } \mathrm{cm}\end{array}$} & \multicolumn{2}{|c|}{$\begin{array}{c}\text { Spruce } \\
\text { proportion in \% }\end{array}$} & \multirow{2}{*}{$\frac{\text { AIC }}{30954}$} \\
\hline \multirow{4}{*}{ Spruce } & All & 20796 & -4.42 & $* * *$ & 0.0158 & $* * *$ & 1.742 & $* * *$ & & -4.79 & $* * *$ & 0.0522 & $* * *$ & 1.631 & $* * *$ & \\
\hline & A & 8878 & -4.12 & $* * *$ & 0.0158 & $* * *$ & 1.374 & $* * *$ & 13904 & -4.55 & $* * *$ & 0.0608 & $* * *$ & 1.093 & $* * *$ & 13565 \\
\hline & B & 7793 & -3.91 & $* * *$ & 0.0141 & $* * *$ & 1.559 & $* * *$ & 13439 & -4.14 & $* * *$ & 0.0467 & $* * *$ & 1.306 & $* * *$ & 13271 \\
\hline & $\mathrm{C}$ & 4123 & -6.11 & $* * *$ & 0.0260 & $* * *$ & 2.058 & $* * *$ & 3349 & -6.12 & $* * *$ & 0.0634 & $* * *$ & 1.949 & $* * *$ & 3416 \\
\hline \multirow{4}{*}{ Beech } & All & 13776 & -6.77 & $* * *$ & 0.0193 & $* * *$ & 2.432 & $* * *$ & 6234 & -6.84 & $* * *$ & 0.0600 & $* * *$ & 2.353 & $* * *$ & 6161 \\
\hline & A & 4144 & -8.37 & $* * *$ & 0.0252 & $* * *$ & 2.774 & $* * *$ & 1053 & -7.23 & $* * *$ & 0.0522 & $* * *$ & 2.290 & $* * *$ & 1128 \\
\hline & B & 5930 & -6.22 & $* * *$ & 0.0165 & $* * *$ & 2.351 & $* * *$ & 3546 & -6.53 & $* * *$ & 0.0607 & $* * *$ & 2.246 & $* * *$ & 3446 \\
\hline & C & 3700 & -7.95 & $* * *$ & 0.0269 & $* * *$ & 3.496 & $* * *$ & 1439 & -7.74 & $* * *$ & 0.0685 & $* * *$ & 3.473 & $* * *$ & 1430 \\
\hline \multirow{4}{*}{ Fir } & All & 7978 & -6.09 & $* * *$ & 0.0149 & $* * *$ & 1.853 & $* * *$ & 4387 & -6.39 & $* * *$ & 0.0481 & $* * *$ & 1.728 & $* * *$ & 4321 \\
\hline & A & 2849 & -7.12 & $* * *$ & 0.0164 & $* * *$ & 2.622 & $* * *$ & 1322 & -7.06 & $* * *$ & 0.0498 & $* * *$ & 2.314 & $* * *$ & 1317 \\
\hline & B & 3460 & -5.59 & $* * *$ & 0.0133 & $* * *$ & 1.684 & $* * *$ & 2244 & -5.78 & $* * *$ & 0.0421 & $* * *$ & 1.490 & $* * *$ & 2215 \\
\hline & C & 1667 & -7.39 & $* * *$ & 0.0232 & $* * *$ & 2.388 & $* * *$ & 776 & -8.02 & $* * *$ & 0.0766 & $* * *$ & 1.953 & $* * *$ & 749 \\
\hline \multirow{4}{*}{ Pine } & All & 1365 & -6.72 & $* * *$ & 0.0222 & $* * *$ & 1.650 & $* * *$ & 737 & -8.12 & $* * *$ & 0.0946 & $* * *$ & 1.628 & $* * *$ & 715 \\
\hline & A & 196 & -6.94 & $* * *$ & 0.0175 & & 1.247 & & 59 & -8.04 & $* * *$ & 0.0820 & . & 1.051 & & 57 \\
\hline & B & 159 & -7.52 & $* * *$ & 0.0110 & & 4.397 & $* *$ & 102 & -9.01 & $* * *$ & 0.0637 & $* *$ & 4.814 & $* *$ & 96 \\
\hline & C & 1008 & -7.50 & $* * *$ & 0.0319 & $* * *$ & 1.676 & $* * *$ & 555 & -8.73 & $* * *$ & 0.1133 & $* * *$ & 1.581 & $* * *$ & 550 \\
\hline \multirow{4}{*}{ Larch } & All & 2344 & -7.86 & $* * *$ & 0.0279 & $* * *$ & 2.589 & $* * *$ & 870 & -7.98 & $* * *$ & 0.0740 & $* * *$ & 2.331 & $* * *$ & 879 \\
\hline & A & 608 & -6.34 & $* * *$ & 0.0082 & . & 2.700 & $* *$ & 277 & -6.28 & $* * *$ & 0.0242 & . & 2.439 & $* *$ & 275 \\
\hline & B & 932 & -7.73 & $* * *$ & 0.0321 & $* * *$ & 1.411 & * & 251 & -7.85 & $* * *$ & 0.0912 & $* * *$ & 0.850 & & 252 \\
\hline & C & 802 & -10.58 & $* * *$ & 0.0530 & $* * *$ & 3.366 & $* * *$ & 296 & -10.89 & $* * *$ & 0.1361 & $* * *$ & 3.214 & $* * *$ & 313 \\
\hline \multirow{4}{*}{$\begin{array}{l}\text { Other } \\
\text { broad- } \\
\text { leaves }\end{array}$} & All & 6194 & -5.85 & $* * *$ & 0.0122 & $* * *$ & $\frac{0.000}{1.432}$ & $* * *$ & 1989 & -6.25 & $* * *$ & 0.0521 & $* * *$ & $\begin{array}{l}.217 \\
1.287\end{array}$ & $* * *$ & 1927 \\
\hline & $\mathrm{A}$ & 1578 & -6.54 & $* * *$ & 0.0064 & & 1.477 & . & 204 & -6.68 & $* * *$ & 0.0300 & * & 1.328 & 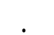 & 202 \\
\hline & B & 2471 & -5.38 & $* * *$ & 0.0102 & $* * *$ & 0.864 & $* *$ & 901 & -5.60 & $* * *$ & 0.0394 & $* * *$ & 0.746 & * & 887 \\
\hline & C & 2143 & $\begin{array}{r}\text { J.Jo } \\
-7.18\end{array}$ & $* * *$ & 0.0288 & $* * *$ & 2.630 & $* * *$ & 801 & -7.67 & $* * *$ & 0.1020 & $* * *$ & 2.079 & $* * *$ & $\begin{array}{l}801 \\
759\end{array}$ \\
\hline
\end{tabular}




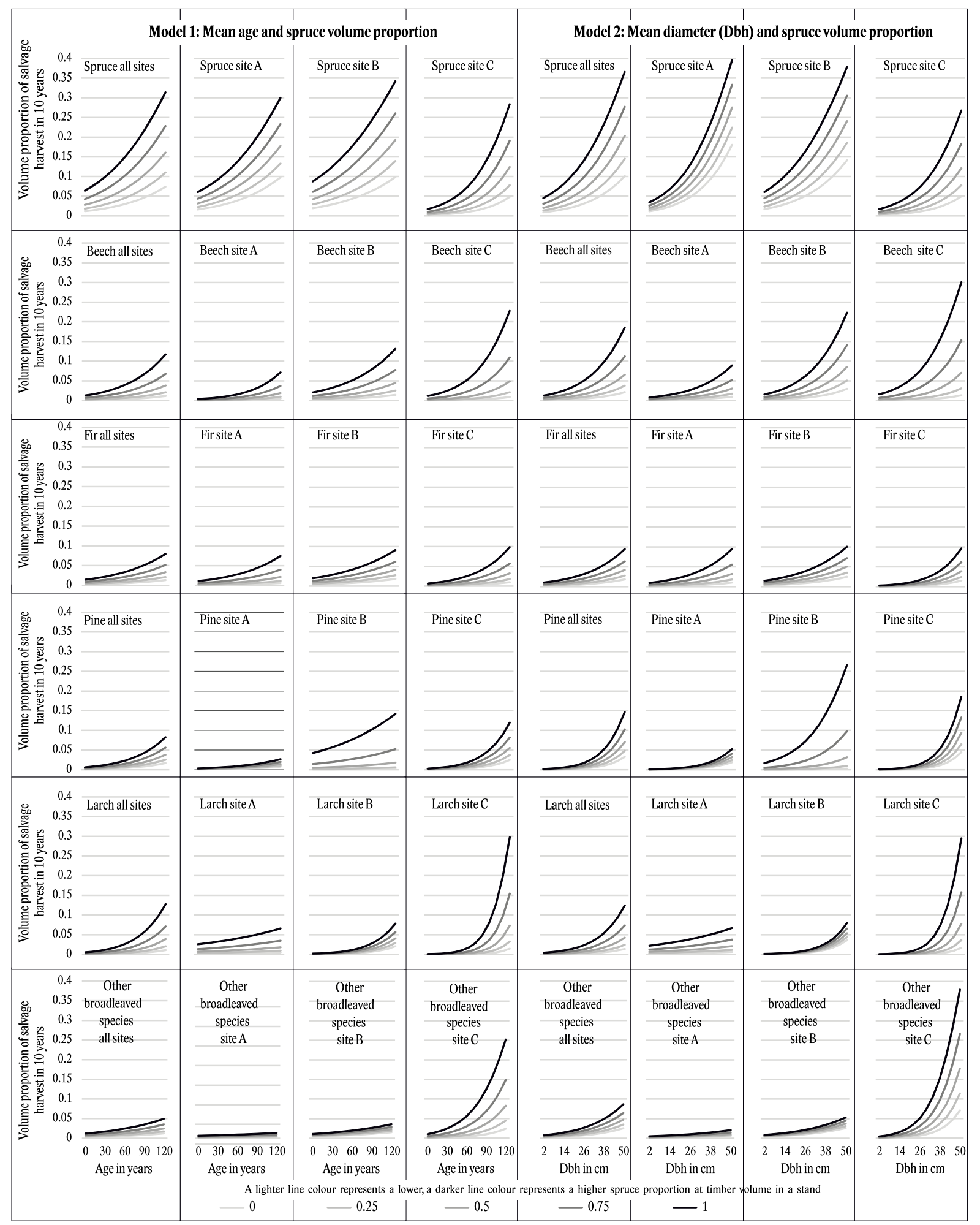

Fig. 3. Binary logistic regression analysis of the volume proportion processed by salvage cutting over a 10 year period for spruce, beech, fir, pine, larch, other broadleaved species dependent on mean age of the species, and dependent on the spruce volume proportion in the stand (Model M1) and dependent on mean diameter (Dbh) of the species, and dependent on the spruce volume proportion in the stand (Model M2), represented for the cases of $0 \%, 25 \%, 50 \%, 75 \%$, and $100 \%$ spruce volume proportion in the stand. 
for Douglas fir (Brandl et al. 2020) and for beech (Paul et al. 2019). Because currently the stabilising effect of a low spruce admixture on other species is not explained in the literature, an effect other than stabilisation might account for the impact of $s p p$ on $s f$ in other species than spruce.

The region of interest is dominated by pure spruce stands, partly with little admixture, and intensive admixture is only present to a lesser extent in the lower parts and foothills. Consequently, in the case of a spruce stand failure, a small proportion of admixed species is also exposed to the failure and so is likely to be damaged by the breakdown of the nearby pure spruce forest stand. Additionally, salvage logging operations might damage or remove the remaining trees of other species. Even in cases where species other than spruce survive the failure event, they are exposed to further risks. Because spruce dominated stands are typically dense, trees develop short and narrow crowns and are not prepared to survive under free-land conditions. In the following years, the stems of remaining trees are suddenly exposed to the sun on the cleared area and can die through drying or being thrown by the wind.

While the continuous stabilisation effects of broadleaved species on spruce are related to the ecology of species mixture, the destabilisation effect of an increasing spp on all the species present is a coincidence caused by a single spruce stand failure event in the neighbourhood. Therefore, the results demonstrate how sensitive species react to destabilising by spruce. Generally, other species demonstrate a lower level of $s f$ when growing in a stand with a high spp, as compared to spruce in a stand with a high spp. This lower $s f$ demonstrates that other species better resist against stand failure compared to spruce; furthermore, they survive the harsh conditions during and after a stand failure event.

The study of the Beskydy Mountains used salvage records on the forest-stand level. This is a methodological difference to most other literature, which used inventory data on the single-tree level. Consequently, salvage records are better suited for calculating total stand failure and stand survival probability than continuous single-tree mortality rates in more intense mixtures. Further argument is the time frame of the salvage-harvest records of the Beskydy study region that covers one single, rapid, large-scale, and long-lasting event of spruce decline which affects whole stands. Contrarily, the previous literature used continuous data on larger, state-wide scales, e.g., between one (Griess et al. 2012) and three German states (Neuner et al. 2015), or on the European level (Paul et al. 2019; Brandl et al. 2020), in which such an event is not necessarily applicable.

Higher spruce $s f$ in the mountainous region (A and B) compared to the sub-mountainous region (C) might be related to the increasing storm intensity with the altitude above sea level. The higher $s f$ of beech and other broadleaved species at the lower altitudes of site $\mathrm{C}$, as compared to sites A and B, corresponds to the warmer climate, which is better biologically suited for the growth of broadleaved species, when compared with conifers. Consequently, broadleaved species on site $\mathrm{C}$ were more dominant, thicker, higher, and therefore more exposed to stand failure compared to broadleaved species at the higher altitudes on sites A and B. The $s f$ of the broadleaved species and of spruce might correlate with a higher proportion of the same species on a site.

The inconsistency of spruce $s f$ between site A and B, when comparing the evaluation dependent on age with the evaluation dependent on $d b h$, might be related to the fertility of the site: For a lower bonity (poor site A), the $d b h$ and the height are lower compared to a higher bonity (richer site B), given the same age. The main exposure to $s f$ is related to $d b h$ (bark-beetle risk) and to height (storm risk), but only indirectly and secondarily to age. The higher spruce $s f$ on site B compared to site A related to age corresponds to the much lower survival probability on good sites compared to bad sites found by Griess et al. (2012) and confirmed by Neuner et al. (2015) to a lesser extent. The reason for the different order might be that the nutrient-rich site $B$ allowed for better growth compared to the acidic site $\mathrm{A}$, and the higher trees were more exposed to stand failure.

The derived failure rates offer the option to implement them in single-tree models, forest-stand simulators, such as Silva or Sibyla, or in size-class structured (e.g., matrix) models. However, the interpretation of the (complete or partial) stand failure as a continuous single-tree mortality rate technically allows for remaining trees that are benefiting from a decreased stand density. Such a procedure might underestimate the extent of a single failure event in a stand which completely interrupts growth.

Regression models that consider the stabilising ecological effects of a proportion of mixed species on failure rates can be integrated into financial optimisation models that include risks (Griess \& Knoke 2013; Roessiger et al. 2013; Neuner \& Knoke 2017; Paul et al. 2019). The method is as follows: multiply the probability of stand failure for a given stand situation with the financial net result and weigh this stand part with a reduction factor, e.g., with $50 \%$ (Dieter 2001) to represent the damage of the timber, higher harvest costs, and reduced timber prices. Therefore, the failure rates can be used to find an optimal way to transform management, not only involving changing environmental conditions, such as changes in the proportion of species, the climate, or the site, but also to adapt to changing financial net incomes.

Regarding matrix modelling, Roessiger et al. (2019) demonstrated in a sensitivity study about Roessiger et al. (2018) how altered mortality rates and other characteristics can be implemented into forest simulation and optimisation. Liang et al. (2011) integrated the effect of continuous changing climatic temperatures and precipitation into their matrix model to demonstrate shifts in species composition. 
Furthermore, mortality rates change over time. Pretzsch et al. (2014) reported that beech mortality in Europe declined within the last century while spruce rate was stable. Griess et al. (2012) and Neuner et al. (2015) introduced climate and site factors into survival analyses by including factors such as water supply and nutrient supply into the regression analysis in addition to tree species ratio. The mortality rates sensitive to climate change the increased financial management risk (Neuner and Knoke 2017). Paul et al. (2019) evaluated the effect of beech admixture and climate variables related to temperature and precipitation on survival under expected climate change scenarios within a financial optimisation under risk.

Tree species mixture not only has a positive economic impact on survival but also on growth. The volume growth in mixed stands made up of single-tree or group-wise mixtures in Europe is 10\% to 30\% faster as compared to neighbouring pure stands (Pretzsch et al. 2010; 2015; Pretzsch \&Biber 2016). Nowadays, spruce and beech need a shorter amount of time to reach the states documented in yield tables because of the higher temperatures, longer vegetation times, more nutrients, and higher $\mathrm{CO}_{2}$ concentrations (Pretzsch et al. 2014). Pretzsch et al. (2020) artificially established summer drought conditions over five years in an experiment by excluding throughfall using a roof. They found that one or more beeches neighbouring a spruce reduced the decline in the growth rate of the spruce and the increase in mortality of the spruce during the drought and allowed for a faster recovery after the drought compared to a spruce in a pure spruce neighbourhood. However, a regional study demonstrated more diverse trends of growth in combination with other events. Bošela et al. (2019) evaluated growth over a hundred years using a tree-ring analysis in Smolícka Osada (Central Slovakia). They found a strong decline in spruce, a slight decline in pine, a slight increase in beech, and a strong recovery for fir, after the declining fir numbers in the 1980 s caused by air pollution. The declining effect of light-demanding species such as spruce and pine might also be explained by a change from even-aged to uneven-aged management in the 1950s (Bošela et al. 2019).

\section{Conclusion}

This study clearly demonstrates an increase in stand failure expressed by salvage-harvest proportion with age (alternatively $d b h)(\mathrm{H} 1)$ and spruce proportion (H2) in the stand. This paper indicates how a lower proportion of spruce and a simultaneously increased proportion of admixed species, to levels of $25 \%$ and higher, significantly reduces stand failure. Our results are based on data from forests managed using the common system of age classes on the stand level, hence they are best suited for modelling even-aged forest management. As a result of the close correlation between age and $d b h$ on the stand level in even-aged forests, the results might be "carefully" utilised for modelling uneven-aged forest management based on diameter distributions or on the tree level. This might be the only way considering the critical lack of data from real uneven-aged forests within the region, especially during the first phase of transition from an even-aged to a stable uneven-aged management system. After a successful transition, matrix modelling may offer potential solutions regarding how to model and to subsequently develop forest management in the long term for cases like that in the Beskydy Mountains. Nevertheless, future research related to management risk and forest modelling should distinguish between the following two interpretations: (1) the mortality of single trees in the sense of a continuous reduction in the number of stems with a regularly scattered spatial distribution over the stand area; and (2) a large-scale failure event removing a complete stand or part of a stand. A realistic forest model should focus on the impact of large-scale failure in forestry characterised by long-lasting disruptions which disallow a continuous management, decreases and fluctuations in financial net income (including timber prices and costs for harvesting, planting, and silvicultural), and uncertainty regarding forest-management planning.

\section{Acknowledgement}

This work was supported by the Slovak Research and Development Agency (Project APVV-18-0195 SilvaMod) and by the Ministry of Agriculture and Rural Development of the Slovak Republic (Item No. 08 V0301 - Project SLOVLES).

This study utilises the database on forest management plans and forest management records created by National Forest Centre (NFC) Zvolen and Global Change Research Institute (GCRI) Brno within the project Interreg SK-CZ BESKYDY (ITMS: 304021D067).

\section{References}

Bolte, A., Ammer, C., Löf, M., Madsen, P., Nabuurs, G. J., Schall, P. et al., 2009:Adaptive forest management in central Europe: Climate change impacts, strategies and integrative concept. Scandinavian Journal of Forest Research, 24:473-482.

Bošel'a, M., Kulla, L., Roessiger, J., Šebeň, V., Dobor, L., Büntgen, U., Lukac, M., 2019: Long-term effects of environmental change and species diversity on tree radial growth in a mixed European forest. Forest Ecology and Management, 446:293-303.

Brandl, S., Paul, C., Knoke, T., Falk, W., 2020: The influence of climate and management on survival probability for Germany"s most important tree species. Forest Ecology and Management, doi: 10.1016/j. foreco.2019.117652. 
Dieter, M., 2001: Land expectation values for spruce and beech calculated with Monte Carlo modelling techniques. Forest Policy and Economics, 2:157-166.

Gayer, K., 1886: Der gemischte Wald. Berlin: Parey.

Griess, V. C., Acevedo, R., Härtl, F., Staupendahl, K., Knoke, T., 2012: Does mixing tree species enhance stand resistance against natural hazards? A case study for spruce. Forest Ecology and Management, 267:284-296.

Griess, V. C., Knoke, T., 2011: Growth performance, wind-throw, and insects: meta-analyses of parameters influencing performance of mixed-species stands in boreal and northern temperate biomes. Canadian Journal of Forest Research, 41:1141-1159.

Griess, V. C., Knoke, T., 2013: Bioeconomic modeling of mixed Norway spruce - European beech stands: economic consequences of considering ecological effects. European Journal of Forest Research, 132:511-522.

Hlásny, T., Barka, I., Roessiger, J., Kulla, L., Trombik, J., Sarvašová, Z. et al., 2017: Conversion of Norway spruce forests in the face of climate change: a case study in Central Europe. European Journal of Forest Research, 136:1013-1028.

Hlásny, T., Sitková, Z. (eds.), 2010: Spruce Forest Decline in the Beskids. National Forest Centre-Forest Research Institute Zvolen \& Czech University of Life Sciences Prague \& Forestry and Game Management Research Institute Jílovišté - Strnady, Zvolen $182 \mathrm{p}$.

Knoke, T., Stimm, B., Ammer, C., Moog, M., 2005: Mixed Forest reconsidered: A Forest Economics Contribution on an Ecological Concept. Forest Ecology and Management, 213:102-116.

Knoke, T., Seifert, T., 2008: Integrating selected ecological effects of mixed European beech - Norway spruce stands in bioeconomic modelling. Ecological Modelling, 210:487-498.

Knoke, T., Ammer, C., Stimm, B., Mosandl, R., 2008: Admixing broadleaved to coniferous tree species: a review on yield, ecological stability and economics. European Journal of Forest Research, 127:89-101.

Kulla, L., Sitková, Z. (eds.), 2012: Rekonštrukcie nepôvodných smrekových lesov: poznatky, skúsenosti, odporúčania. Národné lesnícke centrum - Lesnícky výskumný ústav Zvolen, Zvolen 208 p.

Kunca, A., Zúbrik, M., Galko, J., Vakula, J., Leontovyč, R., Konôpka, B. et al., 2019: Salvage felling in the Slovak Republic's forests during the last twentyyears (1998-2017). Central European Forestry Journal, 65:3-11.

Liang, J., Zhou, M., Verbyla, D. L., Zhang, L., Springsteen, A. L., Malone, T., 2011: Mapping forest dynamics under climate change: A matrix model. Forest Ecology and Management, 262:2250-2262.
Neuner, S., Albrecht, A., Cullmann, D., Engels, F., Griess, V. C., Hahn, W. A. et al., 2015: Survival of Norway spruce remains higher in mixed stands under a dryer and warmer climate. Global Change Biology, 21:935-946.

Neuner, S., Knoke, T., 2017: Economic consequences of altered survival of mixed or pure Norway spruce under a dryer and warmer climate. Climatic Change, 140:519-531.

Pajtík, J., Čihák, T., Konôpka, B., Merganičová, K., Fabiánek, P., 2018: Annual tree mortality and felling rates in the Czech Republic and Slovakia over three decades. Central European Forestry Journal, 64:238-248.

Paul, C., Brandl, S., Friedrich, S., Falk, W., Härtl, F., Knoke, T., 2019: Climate change and mixed forests: how do altered survival probabilities impact economically desirable species proportions of Norway spruce and European beech? Annals of Forest Science, 76:14.

Pretzsch, H., Biber, P, Schütze, G., Uhl, E., Rötzer, T., 2014: Forest stand growth dynamics in Central Europe have accelerated since 1870. Nature Communications, 5:4967.

Pretzsch, H., Block, J., Dieler, J., Phan, H. D., Kohnle, U., Nagel, J. et al., 2010: Comparison between the productivity of pure and mixed stands of Norway spruce and European beech along an ecological gradient. Annals of Forest Science, 67:712.

Pretzsch, H., Biber, P., 2016: Tree species mixing can increase maximum stand density. Canadian Journal of Forest Research, 46:1179-1193.

Pretzsch, H., del Río, M., Ammer, Ch., Avdagic, A., Barbeito, I., Bielak, K.et al., 2015: Growth and yield of mixed versus pure stands of Scots pine (Pinus sylvestris L.) and European beech (Fagus sylvatica L.) analysed along a productivity gradient through Europe. European Journal of Forest Research, 134:927-947.

Pretzsch, H., Grams, T., Häberle, K. H., Pritsch, K., Bauerle, T., Rötzer, T., 2020: Growth and mortality of Norway spruce and European beech in monospecific and mixed-species stands under natural episodic and experimentally extended drought. Results of the KROOF throughfall exclusion experiment. Trees, doi: 10.1007/s00468-020-01973-0.

Roessiger, J., Griess V. C., Härtl, F., Clasen, C., Knoke, T., 2013: How economic performance of a stand increases due to decreased failure risk associated with the admixing of species. Ecological Modelling, 255:58-69.

Roessiger, J., Ficko, A., Clasen, C., Griess, V. C., Knoke, T., 2016:Variability in growth of trees in uneven-aged stands displays the need for optimizing diversified harvest diameters. European Journal of Forest Research, 135:283-295. 
Roessiger, J., Kulla, L., Bošel'a, M., 2018: Finding equilibrium in continuous-cover forest management sensitive to interest rates using an advanced matrix transition model. Journal of Forest Economics, 33:83-94.

Roessiger, J., Kulla, L., Bošel'a, M., 2019: Changes in growth caused by climate change and other limiting factors in time affect the optimal equilibrium of close-to-nature forest management. Central European Forestry Journal, 65:180-190.

Staupendahl, K., Zucchini, W., 2011: Schätzung von Überlebensfunktionen der Hauptbaumarten auf der Basisvon Zeitreihendaten der Rheinland-Pfälzischen Waldzustandserhebung. Allgemeine Forst- und Jagdzeitung, 182:129-145.

Zlatník, A., 1976: Přehled skupin typů geobiocenů původně lesních a křovinných v ČSSR. Zprávy geografického ústavu ČSAV, 13, Brno.

\section{Other sources}

Consortium Beskydy, 2019: A database on forest management plans and forest management records created within the project Interreg SK-CZ BESKYDY (ITMS2014+: 304021D067) by National Forest Centre (NFC) Zvolen and Global Change Research Institute (GCRI) Brno.

R Core Team, 2019: R: Language and Environment for Statistical Computing. R foundation for Statistical Computing, Vienna Austria. http://www.R-project. org/. 